\title{
Epidemiological aspects of human and canine visceral leishmaniasis in Venezuela
}

\author{
Olga Zerpa, ${ }^{1}$ Marian Ulrich, ${ }^{1}$ Rafael Borges, ${ }^{1}$ Vestalia Rodríguez, ${ }^{1}$ \\ Marta Centeno, ${ }^{1}$ Emilia Negrón, ${ }^{1}$ Doris Belizario, ${ }^{1}$ and Jacinto Convit ${ }^{1}$
}

ABSTRACT Objective. To report recent data on the distribution of human and canine visceral leishmaniasis $(V L)$ in Venezuela, and to highlight problems associated with effective control measures. Methods. We report the number of cases, incidence rate, age and sex distribution, and mortality rates for human VL (HVL) for the period of 1995 through 2000, based on National Registry of Leishmaniasis data. We carried out serological studies on a total of 3025 domestic dogs from the 12 states in Venezuela reporting cases of human VL in this 1995-2000 period and also from the state of Yaracuy, where cases were reported earlier during the decade of the 1990s.

Results. From 1995 through 2000, 242 cases of HVL were reported from 12 states, in various sections of Venezuela. There was a relatively stable national incidence rate of 0.2 cases per 100000 persons per year. Of the 242 cases, $26.0 \%$ were from Margarita Island, one of the three islands that make up the state of Nueva Esparta (Margarita Island was the only one of the Nueva Esparta islands that had HVL cases). Over the 1995-2000 period, the annual incidence rates for Nueva Esparta ranged from 1.7 to 3.8 cases per 100000 population. Males in Venezuela were more frequently affected (59.5\%) than were females (40.5\%). In terms of age, $67.7 \%$ of the VL patients were $\leq 4$ years of age, and $80.6 \%$ were younger than 15 years. The mortality rate among the persons with VL was 7.85\% during the 1995-2000 period. Serological screening with rK39 antigen of 1217 dogs from Margarita Island found a 28.5\% positivity rate (testing of dogs was not done on the two other islands of Nueva Esparta). In contrast, the rate was $2.8 \%$ in the 1808 samples from dogs from 12 states on the mainland.

Conclusions. Human and canine VL are unevenly distributed in Venezuela. The distribution may reflect such factors as differences among the states in human population density, vector density, and the presence or absence of other trypanosomatidae. Particularly high infection rates in very young children as well as in domestic dogs occur in semiurban communities of Nueva Esparta, where other human-infecting trypanosomatidae have not been reported. Control measures related to limiting canine infection might contribute to disease control where VL infections are frequent. Reducing VL mortality requires increased awareness among medical professionals of the possibility of VL in the differential diagnosis of hepato-splenic syndromes, particularly in children.

Key words Leishmaniasis, dogs, communicable disease control, Venezuela.

1 Instituto de Biomedicina, Universidad Central de Venezuela/Ministerio de Salud y Desarrollo Social, Caracas, Venezuela. Send correspondence to: Olga Zerpa, Instituto de Biomedicina, Apartado 4043, Caracas 1010A, Venezuela; telephone: 58 (212) 860-4636; fax: 58 (212) 861-1258; e-mail ozerpa@telcel.net.ve
American visceral leishmaniasis (AVL) is a potentially fatal protozoan infection usually caused by Leishmania chagasi (= L. infantum). It is broadly distributed in the New World, from Argentina to the United States of Amer- ica (1-2). L. amazonensis, L. columbiensis, and L. mexicana have occasionally been reported from cases of AVL in individuals without known immunocompromise (3-5). The disease is maintained in nature in a complex epidemiological 
cycle that may include both domestic and wild components; reservoirs include domestic dogs, crab-eating foxes (Cerdocyon thous), South American opossums, and rodents (6). Domestic dogs are probably the reservoir for most infections in susceptible humans, but human-to-human transmission has also been suggested (7). AVL is transmitted to man by the bite of sand flies belonging to the genus Lutzomyia, family Psychodidae. Vectors in Venezuela include $L u$. longipalpis and $L u$. evansi (8). Parasites from two widely separated foci in Venezuela have been identified as Leishmania infantum, zymodeme MON-1 $(9,10)$.

The first autochthonous case of AVL in Venezuela was diagnosed in the central part of the country in 1941 (11). In 1970 Torrealba extensively reviewed 174 cases registered in the country in the period of 1941 through 1969 (unpublished doctoral thesis, University of Carabobo, Valencia, Venezuela). Subsequently, sporadic cases have been reported from widely separated foci throughout much of the country, but systematic studies have been largely limited to an eastern focus. That eastern focus includes Margarita Island, which is one of the three islands that make up the state of Nueva Esparta, as well as several nearby states on the mainland of Venezuela $(12,13)$.

The objective of this study is to report selected epidemiological data on human and canine AVL from Venezuela for the six-year period of 1995 through 2000, including characteristics of human cases and the results of serological screening in domestic dogs. We emphasize problems associated with delay in diagnosis, underreporting, and lack of adequate control methods in this widely distributed endemic disease. We also describe distinctive characteristics of the endemic situation in different foci of infection.

\section{SUBJECTS AND METHODS}

\section{Human cases of AVL}

We have analyzed information from 242 cases of AVL registered in the re- gional Public Health Dermatology Services of the Venezuelan Ministry of Health and Social Development and from hospitals that notified cases during the period of 1995 through 2000. The responsible physician of each regional Dermatology Service reports these data to the National Registry of Leishmaniasis, which is maintained at the Institute of Biomedicine, in Caracas. Clinical cases from the public sector, tentatively diagnosed by clinical criteria, including prolonged febrile syndrome, anemia, and hepatosplenomegaly, were confirmed by hospital personnel by identification of amastigotes in bone marrow aspirates when possible. Serology with formalin-fixed $L$. donovani promastigotes and with specific L. chagasi recombinant k39 antigen has also been widely used at the Institute of Biomedicine for laboratory confirmation in recent years. We obtained nationwide morbidity and mortality data during this six-year period from the National Registry of Leishmaniasis (it should be noted that no deaths from human VL were reported in the year 2000). We used information on incidence to calculate cases per 100000 persons per year for each of the 12 states that reported human VL cases during the 1995-2000 period. We report the variables of age and gender for 232 of the 242 cases registered during the six-year period.

\section{Canine surveys}

We carried out preliminary serological studies on a total of 3025 domestic dogs from 1998 through 2000 in previously defined areas, based on the distribution of human cases. Of this total, we took 1217 samples in Nueva Esparta (samples taken only on Margarita Island) and 1808 from 12 states on mainland Venezuela. In addition to the samples taken from dogs in the 11 states on the mainland reporting human VL during the period, we took a small number of samples in the state of Yaracuy. Cases of human VL were not reported in Yaracuy during the period from 1995 to 2000, but there were reports of cases in the state earlier in the decade of the 1990s. In addition, cases were reported by the regional Public Health Dermatology Services from all the states adjacent to Yaracuy during the period from 1995 through 2000. In urban areas we took samples from dogs within a radius of $200 \mathrm{~m}$ of dwellings in which a human case was reported. The sampling area was extended to $1 \mathrm{~km}$ in rural zones. Samples were taken after obtaining permission from the dogs' owners.

\section{Serological studies}

To process the human and canine serum samples, we used enzymelinked immunosorbent assay (ELISA) techniques that have previously been described in detail $(13,14)$, using promastigotes of $L$. donovani, strain MHOM/IN/80/DD8 and, since 1999, recombinant antigen rK39 isolated from $L$. chagasi (15), generously donated by Dr. Steven Reed of the Infectious Disease Research Institute, Seattle, Washington, United States.

\section{Statistical analyses}

We analyzed the data using the Epi Info computer software program (Centers for Disease Control and Prevention, Atlanta, Georgia, United States).

\section{RESULTS}

This report on epidemiological aspects of AVL in Venezuela is based on data on 242 cases from the National Registry of Leishmaniasis for the 19952000 period. AVL diagnosis in Venezuela has traditionally been based on clinical criteria and parasitological confirmation in bone marrow aspirates. From 1995 to 1998, we utilized serological tests using an ELISA, with formalin-fixed $L$. donovani promastigotes as a complementary laboratory criterion of infection in some cases. Incomplete data for 68 of the 242 patients, from 1997 and 1998, noted 41 amastigote-positive bone marrow determinations, 12 serological confirma- 
TABLE 1. Number, incidence rate, and state location of human visceral leishmaniasis cases reported in Venezuela, 1995-2000

\begin{tabular}{|c|c|c|c|c|c|c|c|c|c|c|c|c|c|c|}
\hline \multirow[b]{3}{*}{ State/Total/Overall } & \multicolumn{12}{|c|}{ Year } & & \\
\hline & \multicolumn{2}{|c|}{1995} & \multicolumn{2}{|c|}{1996} & \multicolumn{2}{|c|}{1997} & \multicolumn{2}{|c|}{1998} & \multicolumn{2}{|c|}{1999} & \multicolumn{2}{|c|}{2000} & \multicolumn{2}{|c|}{ Total/Overall } \\
\hline & No. & Rate $^{a}$ & No. & Rate & No. & Rate & No. & Rate & No. & Rate & No. & Rate & No. & Rate \\
\hline Anzoátegui & 3 & 0.3 & 14 & 1.4 & 12 & 1.1 & 9 & 0.8 & 5 & 0.5 & 13 & 1.1 & 56 & 0.9 \\
\hline Aragua & 1 & 0.1 & 3 & 0.2 & 3 & 0.2 & 2 & 0.1 & 3 & 0.2 & 4 & 0.3 & 16 & 0.2 \\
\hline Bolívar & 0 & 0.0 & 0 & 0.0 & 0 & 0.0 & 0 & 0.0 & 0 & 0.0 & 4 & 0.3 & 4 & 0.1 \\
\hline Carabobo & 0 & 0.0 & 0 & 0.0 & 0 & 0.0 & 0 & 0.0 & 2 & 0.1 & 0 & 0.0 & 2 & 0.02 \\
\hline Cojedes & 0 & 0.0 & 0 & 0.0 & 0 & 0.0 & 0 & 0.0 & 1 & 0.4 & 0 & 0.0 & 1 & 0.1 \\
\hline Falcón & 0 & 0.0 & 0 & 0.0 & 0 & 0.0 & 0 & 0.0 & 2 & 0.3 & 1 & 0.1 & 3 & 0.1 \\
\hline Guárico & 3 & 0.5 & 3 & 0.5 & 1 & 0.2 & 2 & 0.3 & 2 & 0.3 & 1 & 0.2 & 12 & 0.3 \\
\hline Lara & 4 & 0.3 & 9 & 0.6 & 7 & 0.5 & 8 & 0.5 & 13 & 0.8 & 10 & 0.6 & 51 & 0.6 \\
\hline Nueva Esparta & 9 & 2.7 & 12 & 3.5 & 6 & 1.7 & 9 & 2.5 & 14 & 3.8 & 13 & 3.4 & 63 & 3.0 \\
\hline Portuguesa & 0 & 0.0 & 0 & 0.0 & 0 & 0.0 & 0 & 0.0 & 1 & 0.1 & 0 & 0.0 & 1 & 0.02 \\
\hline Sucre & 5 & 0.7 & 2 & 0.3 & 4 & 0.5 & 3 & 0.4 & 2 & 0.2 & 4 & 0.5 & 20 & 0.4 \\
\hline Trujillo & 7 & 1.2 & 2 & 0.4 & 1 & 0.2 & 1 & 0.2 & 0 & 0.0 & 2 & 0.3 & 13 & 0.4 \\
\hline Total/Overall & 32 & 0.2 & 45 & 0.2 & 34 & 0.2 & 34 & 0.2 & 45 & 0.2 & 52 & 0.2 & 242 & 0.2 \\
\hline
\end{tabular}

a The incidence rate is per 100000 population.

tions, and 2 patients diagnosed by clinical criteria, with no information for the remaining 13 patients. Confirmatory tests in 85 of the 97 patients from 1999 and 2000 found positive rK39 serology for 44 patients, identification of amastigotes in bone marrow aspirates for 23 patients, and positivity of both tests for 18 patients. Confirmatory tests were not reported for the remaining 12 patients from 1999 and 2000. The specificity of the reaction with promastigotes, which is no longer used in VL studies in our Institute, is compromised on the mainland of Venezuela by the presence of American cutaneous leishmaniasis (ACL) and Chagas' disease. We have not observed ELISA reactivity in sera from ACL or Chagas' disease using recombinant rK39 antigen. Currently, rk39-based serology is used for confirmation throughout most of the country, with invasive bone marrow aspiration being relatively infrequent. The National Registry at the Institute of Biomedicine does not have the results of specific examinations carried out in other institutions, including the Institute of Tropical Medicine of the Central University of Venezuela and some general hospitals. Nevertheless, nearly all diagnosed cases are reported to the Registry because the Institute of Biomedicine is responsible for the national distribution of meglumine antimoniate (Glucantime ${ }^{\mathrm{TM}}$ ), which is used in treatment.

Venezuela is made up of 23 states, a Federal Dependency that consists of 72 small islands, and a Capital District, where Caracas, the country's capital, is located. From 1995 through 2000, 242 cases of AVL were reported in Venezuela from 12 of the 23 states in the country (Table 1). (No cases were reported from the Federal Dependency or the Capital District.). The incidence per 100000 persons per year is listed in Table 1 and presented graphically in the map in Figure 1. The overall incidence rate registered for Venezuela, 0.2 cases per 100000 persons per year, was stable over this six-year period. Three states in the east-Anzoátegui, Nueva Esparta, and Sucre-were among the 6 states with the highest average (mean) incidence rate, ranging from 0.5 cases to 3.0 cases per 100000 persons per year; $57.4 \%$ of all cases of AVL in Venezuela in this period were diagnosed in this eastern focus. Within this focus, $26.0 \%$ of all cases of human VL reported in Venezuela in the period from 1995 through 2000 were diagnosed on Margarita Island, which is the largest of the three islands that form the state of Nueva Esparta. No cases have been reported from the other two islands, Coche (which is inhabited) and Cubagua (which is uninhabited). Cases were registered each year during the study period in the 3 states of the eastern focus as well as in Aragua, Guárico, and Lara, which are in central and west-central Venezuela.

The number of deaths among the human AVL cases and the mortality rates in the states where deaths occurred during the 1995-2000 study period are shown in Table 2. (No data from the year 2000 are included in Table 2 since no deaths were reported in that year.) The overall mortality rate among the human AVL cases for the six-year period was $7.85 \%$, with extremes of $17.65 \%$ in 1998 and $0 \%$ in 2000. The annual mortality rate was highly variable in the seven states that reported deaths during the period, ranging from $0 \%$ to $100 \%$. This variability is undoubtedly related to the small number of cases registered in many of the states each year.

Data on gender and age were known for 232 of the 242 human VL cases. Males were more frequently affected than were females, representing 59.5\% of the cases reported from 1995 through 2000. No significant difference was observed between the frequency in males $(n=98)$ and females $(n=89)$ in patients less than 15 years old, but there was a highly significant predominance of cases in males in patients 15 and older (40 males vs. 5 females).

In terms of affected age groups, $67.7 \%$ of patients were $\leq 4$ years of age and 
FIGURE 1. Geographical distribution and average incidence rate (cases/100 000 persons per year) of American visceral leishmaniasis in Venezuela, 1995-2000 ${ }^{\text {a }}$

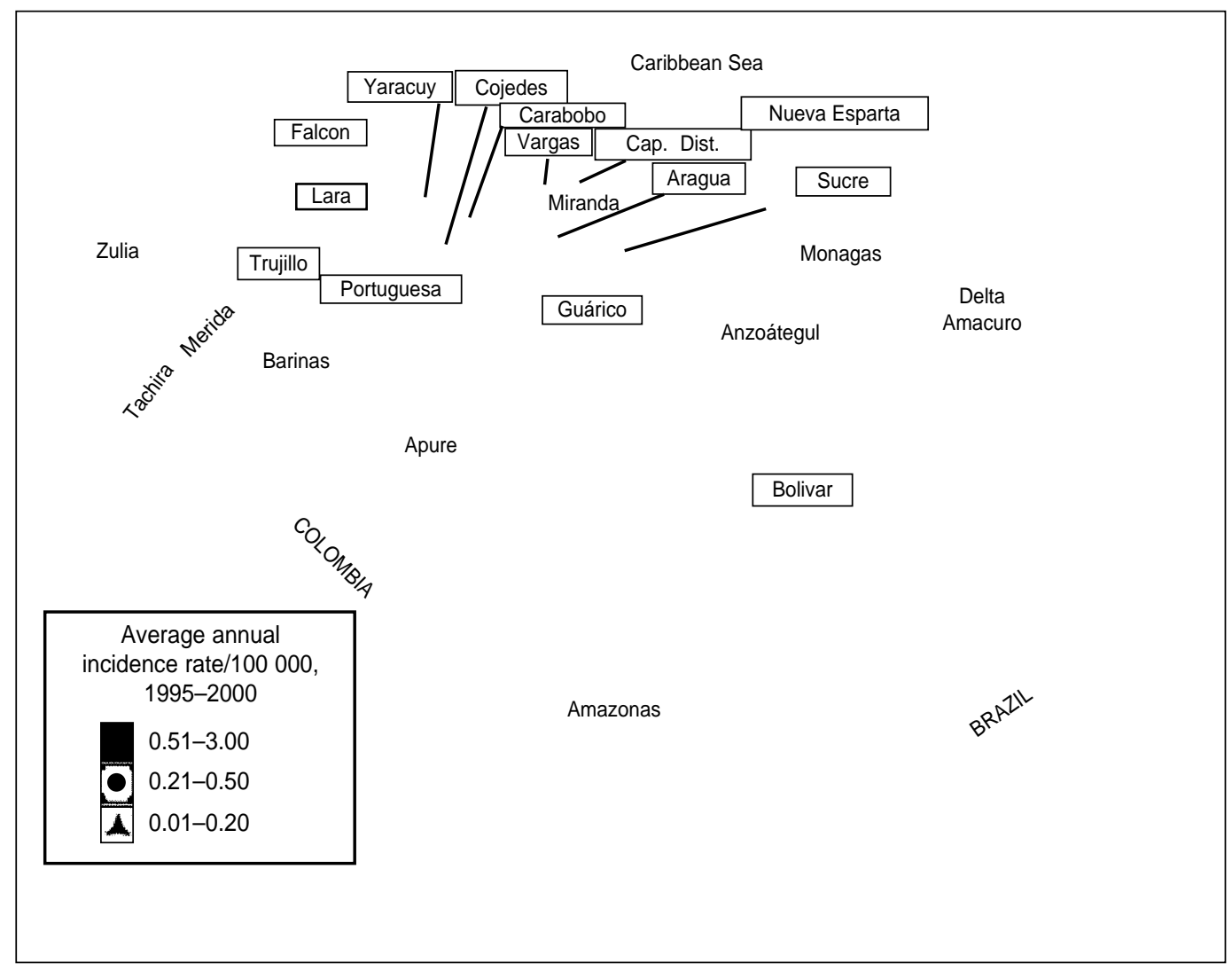

${ }^{\mathrm{a}}$ Cap. Dist. $=$ Capital District, where Caracas, the national capital of Venezuela, is located.

$80.6 \%$ were $\leq 14$ years old (Table 3 ). The average incidence rates during this period showed a progressive decline with age, falling from 1.2/100 000 inhabitants for patients $<2$ years old to $0.05 /$ 100000 for those $>14$ years. Infections in very young children were particularly common in the eastern focus of Nueva Esparta, Anzoátegui, and Sucre, with the highest incidence rate of AVL for this age group in Venezuela. In contrast, infections in a relatively high proportion of patients older than 14 years of age were observed in states in central and west-central Venezuela, where the overall incidence rate of the disease is lower. Three patients from central Venezuela were over 60 years old. The difference in the age distribution of very young patients and those older than 14 years between the eastern focus and the central and west-central area was highly significant $(P<0.001)$. Census data on the general population of Venezuela do not reveal significant differences in age distribution among the states in the country.

On the mainland of Venezuela, the majority of cases were from rural areas. In contrast, the cases on Margarita Island have occurred in semiurban communities. There is no record in the National Registry of Leishmaniasis of AVL among immigrants to Venezuela, or of possible infections acquired in other countries. Two Venezuelan patients with HIV have developed visceral manifestations of leishmaniasis caused by $L$. braziliensis $(16,17)$, but co-infections with HIV and L. chagasi/ infantum have not been reported.

The serological survey of 3025 domestic dogs from 13 states showed an overall positivity of $13.2 \%$ with rK39 antigen (Table 4). When we compared the 1217 samples from Nueva Esparta
(Margarita Island only) with the 1808 samples from the mainland, $28.5 \%$ of the canine samples from Nueva Esparta were positive, versus $2.8 \%$ (range $0 \%$ to $20 \%$ ) of the samples from 12 states on the mainland. Serologically positive samples were not detected in 336 samples from the states of Bolívar, Carabobo, and Portuguesa, in spite of the registry of small numbers of human AVL cases there.

\section{DISCUSSION}

The overall national incidence rates of AVL in Venezuela were relatively constant in the period from 1995 through 2000, although variations did occur in the various states where the disease is endemic. In part, these variations may reflect deficiencies in the respective registries because of the 
TABLE 2. Number of deaths and state mortality rates (\%) among human visceral leishmaniasis cases in seven states of Venezuela reporting deaths, 1995-1999a

\begin{tabular}{|c|c|c|c|c|c|c|c|c|c|c|c|}
\hline \multirow[b]{3}{*}{ State/Total } & \multicolumn{10}{|c|}{ Year } & \multirow[b]{3}{*}{ Total no. } \\
\hline & \multicolumn{2}{|c|}{1995} & \multicolumn{2}{|c|}{1996} & \multicolumn{2}{|c|}{1997} & \multicolumn{2}{|c|}{1998} & \multicolumn{2}{|c|}{1999} & \\
\hline & No. & Rate & No. & Rate & No. & Rate & No. & Rate & No. & Rate & \\
\hline Anzoátegui & 0 & 0.0 & 1 & 7.1 & 1 & 8.3 & 2 & 22.2 & 0 & 0.0 & 4 \\
\hline Aragua & 0 & 0.0 & 1 & 33.3 & 0 & 0.0 & 1 & 50 & 0 & 0.0 & 2 \\
\hline Carabobo & 0 & 0.0 & 0 & 0.0 & 0 & 0.0 & 0 & 0.0 & 2 & 100 & 2 \\
\hline Guárico & 1 & 33.3 & 0 & 0.0 & 0 & 0.0 & 0 & 0.0 & 0 & 0.0 & 1 \\
\hline Lara & 0 & 0.0 & 0 & 0.0 & 1 & 14.3 & 1 & 12.5 & 5 & 38.5 & 7 \\
\hline Nueva Esparta & 0 & 0.0 & 0 & 0.0 & 0 & 0.0 & 2 & 22.2 & 0 & 0.0 & 2 \\
\hline Sucre & 1 & 20.0 & 0 & 0.0 & 0 & 0.0 & 0 & 0.0 & 0 & 0.0 & 1 \\
\hline Total no. & 2 & $N A^{b}$ & 2 & NA & 2 & NA & 6 & NA & 7 & NA & 19 \\
\hline
\end{tabular}

a No deaths were reported for the year 2000.

${ }^{\mathrm{b}} \mathrm{NA}=$ not applicable.

failure to diagnose all cases or to notify them to the National Registry of Leishmaniasis. We cannot adequately estimate underreporting of AVL in Venezuela because of the very low incidence of the disease in much of the country, which is undoubtedly reflected in failures to diagnose sporadic cases. Cases have been reported in only 12 of the 23 states of Venezuela during this 19952000 period, and no cases have been reported in the Federal Dependency or the Capital District. This suggests the existence of currently active localized foci, such as the eastern focus, including Nueva Esparta, Anzoátegui, and Sucre, and the central and west-central states, where the elements involved in transmission are present. Surveillance will be required to detect either expansion of these foci to adjacent states or the appearance of new outbreaks.

Data concerning mortality caused by $\mathrm{VL}$ in the Americas is extremely scarce; $9 \%$ mortality has been reported in an outbreak in the city of Natal, Brazil, with all the deaths occurring during the first week of hospitalization (18). The $7.85 \%$ mortality rate seen in recent years in Venezuela among persons with AVL is substantial and undoubtedly reflects delay in diagnosis and initiation of appropriate treatment. Additional education for medical professionals and such paramedical personnel as public health inspectors and community volunteers working in ambulatory centers in Venezuela is essential for increasing
TABLE 3. Age distribution among 232 cases of human visceral leishmaniasis in Venezuela, 1995-2000

\begin{tabular}{lrrrrr}
\hline & \multicolumn{4}{c}{ Age group (yr) } & \\
\cline { 2 - 5 } State/Total (\%) & $0-1$ & $2-4$ & $5-14$ & $\geq 15$ & Total \\
\hline Anzoátegui & 23 & 14 & 11 & 8 & 56 \\
Aragua & 1 & 4 & 2 & 9 & 16 \\
Bolívar & 0 & 0 & 1 & 3 & 4 \\
Carabobo & 1 & 0 & 1 & 0 & 2 \\
Cojedes & 0 & 0 & 0 & 1 & 1 \\
Falcón & 1 & 0 & 1 & 0 & 2 \\
Guárico & 1 & 0 & 0 & 4 & 5 \\
Lara & 20 & 18 & 2 & 10 & 50 \\
Nueva Esparta & 36 & 18 & 6 & 3 & 63 \\
Portuguesa & 0 & 0 & 0 & 1 & 1 \\
Sucre & 13 & 4 & 1 & 1 & 19 \\
Trujillo & 2 & 1 & 5 & 5 & 13 \\
$\quad$ Total no. & 98 & 59 & 30 & 45 & 232 \\
$\quad \%$ for age group & 42.2 & 25.4 & 12.9 & 19.4 & 100 \\
\hline
\end{tabular}

TABLE 4. Serological reactivity in 3025 serum samples tested for visceral leishmaniasis from domestic dogs in 13 states of Venezuela, 1998-2000

\begin{tabular}{|c|c|c|c|c|}
\hline \multirow[b]{2}{*}{ State/Total/Overall (\%) } & \multirow{2}{*}{$\begin{array}{c}\text { Number of } \\
\text { samples }\end{array}$} & \multicolumn{2}{|c|}{ Positive } & \multirow[b]{2}{*}{$95 \% \mathrm{Cl}^{\mathrm{a}}$} \\
\hline & & No & $\%$ & \\
\hline Anzoátegui & 307 & 17 & 5.5 & $3.4-8.5$ \\
\hline Aragua & 308 & 4 & 1.3 & $0.4-3.1$ \\
\hline Bolívar & 41 & 0 & 0.0 & $0.0-7.0$ \\
\hline Carabobo & 245 & 0 & 0.0 & $0.0-1.2$ \\
\hline Cojedes & 105 & 1 & 1.0 & $0.1-4.6$ \\
\hline Falcón & 5 & 1 & 20.0 & $1.0-66.7$ \\
\hline Guárico & 189 & 12 & 6.3 & $3.5-10.5$ \\
\hline Lara & 146 & 10 & 6.8 & $3.5-11.9$ \\
\hline Nueva Esparta & 1217 & 347 & 28.5 & $26.0-31.1$ \\
\hline Portuguesa & 50 & 0 & 0.0 & $0.0-5.8$ \\
\hline Sucre & 240 & 4 & 1.7 & $0.5-4.0$ \\
\hline Trujillo & 150 & 2 & 1.3 & $0.2-4.3$ \\
\hline Yaracuy & 22 & 0 & 0.0 & $0.0-12.7$ \\
\hline Total/Overall (\%) & 3025 & 398 & 13.2 & $12.0-14.4$ \\
\hline
\end{tabular}

a $95 \% \mathrm{Cl}=95 \%$ confidence interval for percent positive. 
their awareness of this disease entity and for reducing mortality.

In Venezuela the predominance of cases of AVL in males is particularly apparent in older patients. The significant tendency toward infection in very young children in the most active foci of infection and infection at a later age in areas of low endemicity undoubtedly reflect the frequency of exposure to sources of infection. Higher rates of infection in very young children are associated with higher human population density in semiurban areas and a higher infection rate in domestic dogs, particularly in Nueva Esparta. The association that we found between canine infection and the incidence rate of human disease is especially striking.

The situation in the states of Bolívar, Carabobo, and Portuguesa, where small numbers of human cases have been diagnosed but no positive samples were detected in 336 canine specimens, is not particularly surprising. Wild canids or other reservoirs might be involved in maintaining AVL at low levels in these areas. There is no evidence at present that would suggest that human-to-human transmission is significant in Venezuela; multiple cases in single homes have not been reported.

The high proportion of human and canine infections in Nueva Esparta is of considerable interest. All the Nueva Esparta canine samples were taken from the largest island, Margarita, and there are no reports of AVL on the one other inhabited island that forms part of the state. The endemic areas on Margarita Island are essentially all relatively urbanized, with the residents being of marginal or lower middle class economic status. In marked contrast, most cases on the mainland were from rural or semirural areas. While both American cutaneous leishmania- sis and Chagas' disease are endemic on the mainland of Venezuela, no autochthonous cases of these diseases have been reported in Nueva Esparta.

These observations suggest the presence of conditions on Margarita Island that may be particularly favorable for the persistence of the endemicity of AVL. These conditions include a higher population density of humans living in semiurban communities and the absence of other trypanosomatids that produce human disease on the island. These observations may also support the hypothesis suggested in Old World studies that the presence of cutaneous leishmaniasis may diminish the incidence of the visceral form of disease (19). Since Nueva Esparta is an important destination for tourists from both Venezuela and other countries, control measures are particularly important.

The control of visceral leishmaniasis in the New World is largely based on four components: case-finding, opportune treatment, reservoir control, and vector control. In Brazil, according to Costa and Vieira (20), the weakest component may be reservoir control, and vector control should be the highest priority. VL in Venezuela and neighboring Brazil share common features, such as the importance of the domestic dog as an important reservoir, infection by the same species of Leishmania, and transmission by the Lutzomyia longipalpis vector. The extensive experience in the control of VL in Brazil offers helpful information for the design of control programs in Venezuela. Collars impregnated with deltamethrin reduce transmission of VL in the canine population $(21,22)$. Over the long term, use of the collars would presumably decrease the incidence of human disease.

Nevertheless, the precarious economic situation of persons in the areas of Venezuela that are endemic for AVL would inevitably require a firm commitment by national health officials to provide dog collars and such other vector-control measures as bed nets and insecticide spraying in and around residences of patients or of households with infected dogs. Attempts to develop an effective vaccine for use in domestic dogs in areas with a high rate of canine infection should be pursued, since mathematical models suggest that effective vaccination would be second only to vector control in reducing the incidence of the disease (23).

With the notable exception of Nueva Esparta, the low incidence of AVL in much of Venezuela presents a daunting challenge to establishing effective control measures. The only practical measure that can be envisioned for much of the mainland is to increase awareness and consideration of AVL in the differential diagnosis of all cases of hepato-splenic syndromes or prolonged febrile states, particularly in children, in order to establish the definitive diagnosis and to initiate specific treatment without delay.

Acknowledgements. We wish to thank the medical and paramedical personnel of the regional Public Health Dermatology Services and the public health inspectors from the Institute of Biomedicine for their diligence in collecting both information and canine blood samples. The generous donation of rK39 antigen by Dr. Steven Reed of the Infectious Disease Research Institute, Seattle, Washington, United States of America, is gratefully acknowledged. This study was partially financed by grants VEN/96/002-021025 and 002-021-049, World Bank/ Government of Venezuela Agreement.

\section{REFERENCES}

1. Grimaldi G Jr, Tesh RB, McMahon-Pratt D. A review of the geographic distribution and epidemiology of leishmaniasis in the New World. Am J Trop Med Hyg 1989;41(6):687-725.

2. Momen H, Grimaldi G Jr., Deane LM. Leishmania infantum, the aetiological agent of
American visceral leishmaniasis (AVL)? Mem Inst Oswaldo Cruz 1987;82(3):447448.

3. Barral A, Badaró R, Barral-Netto M, Grimaldi G Jr, Momen H, Carvalho EM. Isolation of Leishmania mexicana amazonensis from the bone marrow in a case of American visceral leishmaniasis. Am J Trop Med Hyg 1986; 35(6):732-734.

4. Delgado O, Castés M, White AC, Kreutzer RD. Leishmania colombiensis in Venezuela. Am J Trop Med Hyg 1993;48(1):145-147. 
5. Monroy-Ostria A, Hernández-Montes O, Barker DC. Aetiology of visceral leishmaniasis in Mexico. Acta Trop 2000;75(2):155-161.

6. Lainson R. The American leishmaniases: some observations on their ecology and epidemiology. Trans R Soc Trop Med Hyg 1983; 77(5):569-595.

7. Evans TG, Texeira MJ, McAuliffe IT, Vasconcelos IAB, Vasconcelos AW, Sousa AQ, et al. Epidemiology of visceral leishmaniasis in northeast Brazil. J Inf Dis 1992;166(5):1124-1132.

8. Feliciangeli MD, Rodríguez N, De Guglielmo $\mathrm{Z}$, Rodríguez A. The re-emergence of American visceral leishmaniasis in an old focus in Venezuela. II. Vectors and parasites. Parasite $1999 ; 6(2): 113-120$.

9. Moreno G, Scorza JV, Añez N. Leishmania infantum en el estado Trujillo, Venezuela. Acta Cient Venezol 1990;41(Supl.1):27.

10. Zerpa O, Pratlong F, Ulrich M, Convit J. Isolation of Leishmania infantum, zymodeme MON1 from canine and human visceral leishmaniasis on Margarita Island, Venezuela. Mem Inst Oswaldo Cruz 2001;96(7):901-902.

11. Martínez NA, Pons AR. Primer caso de kalaazar en Venezuela. Gaceta Med Caracas 1941; 48(4):329-332.

12. Zulueta AM, Villarroel E, Rodríguez N, Feliciangeli MD, Massarri M, Reyes O, et al. Epidemiologic aspects of American visceral leishmaniasis in an endemic focus in eastern
Venezuela. Am J Trop Med Hyg 1999;61(6): 945-950.

13. Zerpa O, Ulrich M, Negrón E, Rodríguez N Centeno M, Rodríguez V, et al. Canine visceral leishmaniasis on Margarita Island (Nueva Esparta, Venezuela). Trans R Soc Trop Med Hyg 2000;94(5):484-487.

14. Ulrich M, Rodríguez V, Centeno M, Convit J. Differing antibody IgG isotypes in the polar forms of leprosy and cutaneous leishmaniasis characterized by antigen-specific $\mathrm{T}$ cell anergy. Clin Exp Immunol 1995;100(1):54-58.

15. Burns JM Jr, Sheffler WG, Bensen DR, Ghalib HW, Badaró R, Reed SG. Molecular characterization of a kinesin-related antigen of Leishmania chagasi that detects specific antibody in African and American visceral leishmaniasis. Proc Natl Acad Sci USA 1993;90(2):775-779.

16. Hernández DE, Oliver M, Martínez C, Planas $\mathrm{G}$. Visceral leishmaniasis with cutaneous and rectal dissemination due to Leishmania braziliensis in acquired immunodeficiency syndrome (AIDS). Int J Dermatol 1995;34(2):114115.

17. Loyo N, Zerpa OR, Oliver M, Capozzi V, Arenas A, Rodríguez N, et al. HIV and leishmaniasis coinfection. Ann Dermatol Venereol 2002;129:1S810.

18. Jerónimo SM, Oliveira RM, Mackey S, Costa RM, Sweet J, Nascimiento ET, et al. An urban outbreak of visceral leishmaniasis in Natal,
Brazil. Trans R Soc Trop Med Hyg 1994;88(4): 386-388.

19. Ozensoy S, Ozbel Y, Turgay N, Alkan MZ, Gul K, Gilman-Sachs A, et al. Serodiagnosis and epidemiology of visceral leishmaniasis in Turkey. Am J Trop Med Hyg 1998;59(3):363369.

20. Costa CHN, Vieira JBF. Mudanças no controle da leishmaniose visceral no Brasil/Changes in the control program of visceral leishmaniasis in Brazil. Rev Soc Bras Med Trop 2001; 34(2):223-228.

21. Killick-Kendrick R, Killick-Kendrick $M$ Foucheux MC, Dereure J, Puech MP, Cadiergues MC. Protection of dogs from bites of phlebotomine sandflies by deltamethrin collars for control of canine leishmaniasis. Med Vet Entomol 1997;11(2):105-111.

22. David JR, Stamm LM, Bezerra HS, Souza RN, Killick-Kendrick R, Lima JW. Deltamethrinimpregnated dog collars have a potent antifeeding and insecticidal effect on Lutzomyia longipalpis and Lutzomyia migonei. Mem Inst Oswaldo Cruz 2001;96(6):839-847.

23. Dye C. The logic of visceral leishmaniasis control. Am J Trop Med Hyg 1996;55(2):125-130.

Manuscript received 26 March 2002. Revised version accepted for publication on 15 November 2002.
RESUMEN

\section{Aspectos epidemiológicos} de la leishmaniasis visceral humana y canina en Venezuela
Objetivo. Dar a conocer datos recientes acerca de la distribución de la leishmaniasis visceral (LV) humana y canina en Venezuela y resaltar los problemas que se asocian con la aplicación de buenas medidas de control.

Métodos. Damos a conocer el número de casos, la tasa de incidencia, la distribución por edad y sexo y las tasas de mortalidad de la LV humana (LVH) durante el período de 1995 a 2000, según datos obtenidos del Registro Nacional de Leishmaniasis. Llevamos a cabo pruebas serológicas en un total de 3025 perros domésticos de los 12 estados de Venezuela que notificaron casos de LV en este período, y también de Yaracuy, donde se notificaron casos en los primeros años del decenio de los noventa del siglo pasado.

Resultados. De 1995 a 2000 se notificaron 242 casos de LVH en los 12 estados en distintas partes de Venezuela. Hubo una tasa de incidencia nacional relativamente estable de 0,2 casos por 100000 habitantes al año. De los 242 casos, 26,0\% eran de Isla Margarita, una de las tres islas que integran el estado de Nueva Esparta (Isla Margarita fue la única de las islas de Nueva Esparta que tuvo casos de LVH). Durante el período de 1995-2000, la incidencia anual en Nueva Esparta osciló de 1,7 a 3,8 casos por 100000 habitantes. Los hombres en Venezuela se vieron afectados con mayor frecuencia $(59,5 \%)$ que las mujeres (40,5\%). En cuanto a la edad, 67,7\% de los pacientes con LV tenían 4 años de edad y 80,6\% tenían menos de 15 años. La tasa de mortalidad entre las personas con LV fue de 7,85\% durante el período de 1995-2000. El tamizaje serológico con antígeno rK39 en 1217 perros de Isla Margarita detectó una tasa de positividad de 28,5\% (no se les efectuaron pruebas a los perros de las otras dos islas de Nueva Esparta). En cambio, la tasa fue de 2,8\% en las 1808 muestras tomadas de perros en los 12 estados en tierra firme.

Conclusiones. La LV humana y canina no están uniformemente distribuidas en Venezuela. La distribución podría reflejar factores tales como diferencias entre los estados en términos de densidad poblacional humana, densidad vectorial y la presencia o ausencia de otros tipos de tripanosomas. Se observan tasas especialmente elevadas de infección en niños muy pequeños, así como en perros domésticos, en comunidades semiurbanas de Nueva Esparta, donde no se ha notificado la presencia de otros tripanosomas capaces de infectar al ser humano. Las medidas de control destinadas a limitar la infección canina podrían contribuir al control de la enfermedad en sitios con una alta frecuencia de LV. Para reducir la mortalidad por LV es preciso lograr que los profesionales de la medicina cobren mayor conciencia de la posibilidad de que la LV sea uno de los diagnósticos diferenciales en casos que cursen con síndromes hepatoesplénicos, especialmente en niños. 